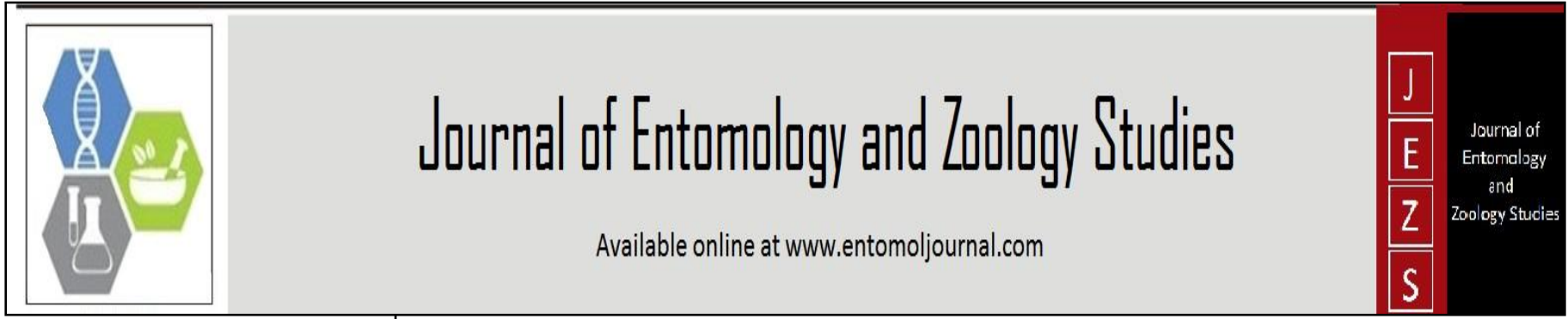

E-ISSN: 2320-7078

P-ISSN: 2349-6800

www.entomoljournal.com

JEZS 2020; 8(6): 1779-1781

(C) $2020 \mathrm{JEZS}$

Received: 03-09-2020

Accepted: 18-10-2020

\section{Kamal Kumar}

Division of Extension Education,

Indian Veterinary Research

Institute, Izatnagar, Bareilly,

Uttar Pradesh, India

Mahesh Chander

Division of Extension Education,

Indian Veterinary Research

Institute, Izatnagar, Bareilly,

Uttar Pradesh, India

\section{VB Dixit}

Central Institute for Research on Buffaloes, Hisar, Haryana, India

\section{Lalita Garg}

Division of Livestock Products Technology, Indian Veterinary Research Institute, Izatnagar, Bareilly, Uttar Pradesh, India

\section{Corresponding Author:}

\section{Kamal Kumar}

Division of Extension Education,

Indian Veterinary Research

Institute, Izatnagar, Bareilly,

Uttar Pradesh, India

\section{Identification of stakeholders who influence buffalo development in Haryana}

\author{
Kamal Kumar, Mahesh Chander, VB Dixit and Lalita Garg
}

DOI: $\underline{\text { https://doi.org/10.22271/j.ento.2020.v8.i6x.8078 }}$

\section{Abstract}

The present study was carried out in Haryana. Six blocks from three districts formed the part of the study and twenty buffalo farmers from each block were selected randomly to arrive at a total sample size of 120 farmers. An ex-post facto research design was used in the present study. Data for the study was collected from primary and well as secondary sources. It has been identified that Buffalo farmers, Scientists, Field functionaries, Input agencies, Administrators and planners, and NGOs were the major stakeholders who influence the buffalo development and milk production of the state. The responses regarding contact of buffalo farmers with information providing stakeholders were retrieved on a threepoint continuum viz. often, occasionally, and never. More than one-third of the respondents $(40.83 \%)$ had occasionally contacted SDAH personnel followed by often $(37.50 \%)$ and never $(21.67 \%)$ contacted SDAH personnel. Around each one-third of the respondents often $(35.00 \%)$, occasionally $(33.33 \%)$ and never $(31.67 \%)$ contacted state veterinary university scientists. More than one third $(37.50 \%)$ of the respondents had never contacted dairy cooperatives while 32.50 percent, occasionally and 30.00 percent often contacted dairy cooperatives.

Keywords: Buffalo development, buffalo farmers, extension agency contact, field functionaries, input agencies

\section{Introduction}

Buffalo is preferred over white cattle in many parts of the country owing to its superior quality of milk, disease resistance, longer productive life, and higher milk productivity. Therefore, it is no surprise that while the cattle population is witnessing a downward trend; the buffalo population has increased by 3.19 percent during the 19 th livestock census ${ }^{[1]}$.

Buffaloes hold the greatest promise to protein-rich milk, its production for human consumption, and sustainable development in the 21st century, as these animals form an integral part of the typical farming system in India ${ }^{[2]}$. They are becoming more economical under the pressure of a decline in the size of holdings ${ }^{[3]}$. Livestock development in general and buffalo development, in particular, is a function of a number of factors viz., buffalo breeds, health cover, livestock management, feeding management, marketing price, and livestock information. Buffalo development is not the sole mandate of a single organization. The development of buffalo is the shared effort of all actors that explicitly and implicitly participate in the different activities of livestock development. Thus, research, extension, and other actors play a vital role to drive the buffalo development of the country ${ }^{[4]}$. It necessitates the integrated action of various stakeholders' viz., scientists, extensionists, subject matter specialists, input suppliers, marketing agencies, livestock agencies, cooperatives, and farmers. All the agencies of livestock development like research institutions, development departments, cooperatives, animal health service providers, non-governmental organizations, financial institutions are engaged in performing one or the other task related to livestock development in general and buffalo development in particular.

\section{Materials and Methods}

The present study was carried out in Haryana. Six blocks formed the part of the study and twenty buffalo farmers from each block were selected randomly to arrive at a total sample size of 120 farmers. An ex-post facto research design was used for the study. For data collection primary as well as secondary sources were used.

\section{Results and Discussion}

Stakeholders who influences buffalo development

Based on the response of the farmers as well as a review of literature of researches done in the 
field of livestock extension and various reports submitted by different committees from time to time, it has been identified that Buffalo farmers, Scientist, Field functionaries, Input agencies, Administrators and planners and NGOs were the major stakeholders who influence the buffalo development and milk production of the state.

The scientists of ICAR institutes viz., Central Institute for Research on Buffaloes, National Dairy Research Institute and National Bureau of Animal Genetic Resources and Lala Lajpat Rai University of Veterinary and Animal Sciences were generating and transferring technologies and information on scientific buffalo husbandry practices to the farmers through various modes of interaction like training, buffalo melas, demonstrations and visit to university.

Field functionaries of the State Department of Animal Husbandry were responsible for providing veterinary healthcare services and information on improved buffalo husbandry practices through different modes of interaction viz., clinical camps, infertility camps, vaccination campaigns, and milk recordings.

Farmers amongst themselves shared information on buffalo farming mostly in an informal setting but formal modes were also used by them like panchayat meetings, milk recordings, and cooperative meetings.

As for as input agencies were concerned cooperatives, government agencies and private agencies were the major stakeholders. Farmers' cooperative was the main source of credit for the farmers. Dairy cooperatives viz., Vita and Mother Dairy were responsible for the dissemination of market-related information and input supply to the farmers. Concerning government agencies banks viz., National Bank for Agriculture and Rural Development (NABARD) and Punjab National Bank (PNB) were the main stakeholders in the study area and they were acting as a main source of farm credit besides farm cooperatives. In private input agencies, pharmaceutical companies were the major players who were responsible for dissemination of healthcare related information to the farmers. The important modes of interaction with input agencies were training, buffalo melas, clinical camps and cooperative meetings.

Non-government organizations (NGOs) were also playing a vital role in buffalo development by technology transfer and information dissemination. The main NGO working in the state was JK trust; NGO personnel were involved in providing artificial insemination (AI) services at the farmers' doorstep. Administrators and planners who were responsible for framing policies on buffalo development included administrators of the ICAR institutes, state veterinary universities, state animal husbandry department, nongovernment organizations and banks. The major modes of interaction with administrators and planners were training, demonstrations, vaccination campaigns, buffalo melas, milk recordings and visit to university.

Similar findings were observed by ${ }^{[5]}$ who conducted a study on interaction of dairy farmers with different agencies in Haryana and found that actors who influence dairy development were dairy farmers, dairy cooperatives, researchers, extension functionaries, administrators and planners, non-governmental organizations and input agencies.

Distribution of respondents according to their contact with different stakeholders: As indicated in Table1, a sizeable population of the respondents (40.83\%) had occasionally contacted SDAH personnel followed by often
(37.50\%) and never (21.67\%) contacted SDAH personnel. Around each one-third of the respondents often $(35.00 \%)$, occasionally $(33.33 \%)$ and never $(31.67 \%)$ contacted SVU scientists.

More than one third (37.50\%) of the respondents had never contacted dairy cooperatives while 32.50 percent, occasionally and 30.00 percent often contacted dairy cooperatives. It was found that more than one-third of the farmers had never contacted with dairy cooperatives. It might be due to inefficient management and delayed payment by the cooperatives that made them not to contact dairy cooperatives as an information source as well as milk procurement agency. An overwhelming majority $(90.00 \%)$ of the respondents contacted other farmers while remaining 10.00 percent of farmers occasionally contacted other farmers. Results revealed that there was no farmer who never contacted other farmers. It might be due to the accessibility and availability of the other farmers and social relationships exists amongst themselves in sharing information.

Around half $(48.34 \%)$ of the respondents never contacted NGOs followed by 30.83 percent and 20.83 percent who contacted NGOs occasionally and often, respectively. Most of the respondents $(43.34 \%)$ occasionally contacted ICAR institutes and almost equal $(42.50 \%)$ proportion of respondents who never contacted ICAR institutes, while 14.16 percent of the respondents often contacted ICAR institutes.

The distant location of ICAR institutes and individual variation in cosmopoliteness and mobility of farmers could be the reason behind this variation in accessing information from ICAR institutes.

More than half $(50.83 \%)$ of the respondents never contacted administrators and planners followed by 32.50 percent and 16.67 percent who contacted administrators and planners occasionally and often, respectively. It was also found that most of the respondents $(46.67 \%)$ contacted private input agencies occasionally followed by 33.33 percent who contacted private input agencies often while remaining 20.00 percent never contacted private input agencies. The results revealed that farmers' contact with private input agencies were more in comparison to government input agencies reason might be the outperformance of private agencies to increase their business.

More than half $(51.67 \%)$ of the buffalo farmers never contacted government input agencies followed by 35.83 percent who occasionally contacted government input agencies, while remaining 12.50 percent of respondents had often contacted government input agencies. The findings were supported by ${ }^{[6]}$ who conducted a study in Sitapur district of Uttar Pradesh, revealed that major sources of farm information were progressive farmers $(53.33 \%)$ and input dealers $(41.60 \%)$, market-related information was mostly accessed through input dealer $(65.00 \%)$ and progressive farmers $(50.00 \%)$. Similar results were also reported by ${ }^{[7]}$ who conducted a study on effectiveness of breeding services of animal husbandry department in Haryana, observed that among formal sources, state department of animal husbandry personnel (2.83) was one of the most frequently contacted extension agents followed by private veterinarians (1.20), Krishi Vigyan Kendras (1.09) and university personnel (1.05) to seek the information related to animal husbandry.

\section{Conclusion}

The major stakeholders who influence buffalo development in 
the state were buffalo farmers, scientists, SDAH field functionaries, input agencies, administrators and planners and Non-government organizations. Scientists of ICAR institutes and State Veterinary University generated technologies which were passed on to State Department of Animal Husbandry field functionaries/veterinarians. Farmers were supposed to utilize these technologies and information. Administrators from ICAR institutes, State Veterinary University, State Department of Animal Husbandry, Non-government organizations, cooperatives and banks were responsible for framing policies while input agencies viz., farmers' cooperatives, dairy cooperatives, government input agencies and private input agencies were responsible for milk procurement, supply inputs like feed, fodder, and credit, etc. Non-government organizations were engaged in the transfer of technology to the farmers.

\section{Acknowledgements}

The authors are grateful to Director IVRI and Director CIRB for providing the facilities to carry out this work. The authors are also thankful to the Punjab National Bank personnel and Veterinary Surgeons posted in the research area for the help and support they provided.

Table 1: Distribution of respondents according to their contact with different stakeholders

\begin{tabular}{|c|c|c|c|c|c|c|c|c|c|}
\hline $\begin{array}{c}\text { Contact with } \\
\text { stakeholders }\end{array}$ & $\begin{array}{c}\text { SDAH } \\
\text { personnel } \\
(\mathbf{n = 1 2 0})\end{array}$ & $\begin{array}{c}\text { SVU } \\
\text { scientists } \\
(\mathbf{n = 1 2 0})\end{array}$ & $\begin{array}{c}\text { Dairy } \\
\text { cooperatives } \\
(\mathbf{n = 1 2 0})\end{array}$ & $\begin{array}{c}\text { Other } \\
\text { farmers } \\
(\mathbf{n = 1 2 0})\end{array}$ & $\begin{array}{c}\text { NGOs } \\
(\mathbf{n = 1 2 0})\end{array}$ & $\begin{array}{c}\text { ICAR } \\
\text { institutes } \\
(\mathbf{n = 1 2 0})\end{array}$ & $\begin{array}{c}\text { Administrators } \\
\text { and planners } \\
(\mathbf{n = 1 2 0})\end{array}$ & $\begin{array}{c}\text { Private input } \\
\text { agencies } \\
(\mathbf{n}=\mathbf{1 2 0})\end{array}$ & $\begin{array}{c}\text { Government } \\
\text { input agencies } \\
(\mathbf{n}=\mathbf{1 2 0})\end{array}$ \\
\hline Never & $26(21.67)$ & $38(31.67)$ & $45(37.50)$ & $0(0.00)$ & $58(48.34)$ & $51(42.50)$ & $61(50.83)$ & $24(20.00)$ & $62(51.67)$ \\
\hline Occasionally & $49(40.83)$ & $40(33.33)$ & $39(32.50)$ & $12(10.00)$ & $37(30.83)$ & $52(43.34)$ & $39(32.50)$ & $56(46.67)$ & $43(35.83)$ \\
\hline Often & $45(37.50)$ & $42(35.00)$ & $36(30.00)$ & $108(90.00)$ & $25(20.83)$ & $17(14.16)$ & $20(16.67)$ & $40(33.33)$ & $15(12.50)$ \\
\hline
\end{tabular}

\section{References}

1. http://dahd.nic.in/sites/default/filess/Annual\%20Report\% 202016-17 5 September, 2018.

2. Manohar DC, Manohar MS, Choudhary D, Rathore VS. Constraints perceived in adoption of recommended management practices by buffalo owners in the Jaipur district of Rajasthan. Journal of Dairy, Veterinary and Animal Research 2015;2(1):13-14.

3. Elumalai K, Pandey UK. Growth and Density Scenario of Livestock and Poultry in Haryana. Indian Journal of Animal Science 2003;73(10):1168-1173.

4. Wodajo Workneh A, Ponnusamy K. Actor linkage in dairy production in West Shewa zone of Oromia, Ethiopia. Indian Journal of Dairy Science 2017;70:(3).

5. Dixit VB, Laharia SN, Bhardwaj A. A critical analysis of interactions among different sub-systems of dairy development. Indian Research Journal of Extension Education 2005;5(2-3):15-18.

6. Burman RR, Dubey SK, Sharma JP, Vijayaragawan K, Sangeetha V, Singh I. Information dynamics for designing cyber extension model for agriculturedevelopment. Journal of Community Mobilizat ion and Sustainable Development 2013;8(2):182-185.

7. Yadav R. Effectiveness of breeding services of animal husbandry department of Haryana. Ph.D. Thesis, IVRI, Izatnagar, Uttar Pradesh, 2018. 